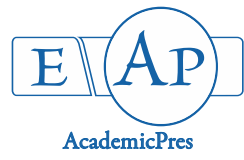

\title{
Impact of Heat Stress on Blood and Serum Biochemistry Parameters in Rats
}

\author{
Rita I. ODO ${ }^{1 *}$, Samuel O. ONOJA2 ${ }^{2}$ Cyrus O. OSUAGWU ${ }^{1}$ \\ ${ }^{1}$ University of Nigeria, Department of Veterinary Physiology and Pharmacology, Nsukka, \\ Nigeria; rita.odo@unn.edu.ng (*correspondingauthor); cyob@yahoo.com \\ ${ }^{2}$ Michael Okpara University of Agriculture, Department of Veterinary Physiology and Pharmacology, Umudike, Nigeria; samonreal@yahoo.com
}

\begin{abstract}
Twenty mature albino rats randomly assigned to two groups $(n=10)$ were used for the study. Group A was exposed to the sun, while group B was kept under a shade. The study was for 28 days. At the end of the study, the effects of heat stress on haematology and serum biochemistry were determined. There was a significant increase $(P<0.05)$ in the packed cell volume of group A when compared to group B. Red blood cell count of group A increased significantly when compared to group B. The mean erythroid values for MCHC and $\mathrm{MCH}$ decreased significantly in group A when compared to group B. The mean haemoglobin concentration of group A was significantly lower when compared to that of group B. White blood cell count of group A decreased significantly $(\mathrm{p}<0.05)$ when compared to group B on day 28 . The result of the differential leucocyte count showed significant decrease in lymphocytes in the heat stressed group when compared to the unstressed for the entire period. Total serum protein significantly increased in group A when compared to group B on day 14 . Alanine amino transferase significantly increases in group A when compared to group B on day 28. Alkaline phosphatase decreased significantly in group A throughout the study period when compared to group B. Aspartate - amino transferase increased significantly in group A when compared to group B on day 28. Serum cholesterol significantly decreased in group A on day 28 when compared to group B.
\end{abstract}

Keywords: alkaline phosphatase; cholesterol; haemoglobin; leucocyte

\section{Introduction}

Most of the world's domestic animal populations are in regions where environmental stressors adversely affect productive efficiency (Gaughan et al., 1999). Annual economic losses due to heat stress (HS) alone for the US livestock industry have been estimated between $\$ 1.69$ to 2.36 billion (St-Pierre et al., 2003).

Clinical signs commonly observed in HS animals include decreased feed intake, body weight, blood calorigenic hormones (i.e. T4, T3) (Mitra et al., 1972; Wolfenson, 2001), and increased prolactin (PRL) levels (Wolfenson, 2001). Cattle exhibit decreased T3 and T4 concentrations (33\% and 15\%, respectively) during summer months but increase concentrations during winter months (Johnson and Stark, 1989). Reduced thyroid hormone levels under HS conditions are due to the complex neuroendocrine processes related to interactions among thermossensors, hypothalamus, pituitary and thyroid glands
(Cooper and Washburn, 1998). Jordan (2003) observed elevated PRL levels in heifers at $32^{\circ} \mathrm{C}$, but reduced levels at $4.5^{\circ} \mathrm{C}$ compared to the animals maintained at $21^{\circ} \mathrm{C}$.

Heat stress exposure increases circulating PRL levels in rats (Costrini et al., 1979), goats (Brosh et al., 1988), sheep (Brosh et al., 1988), and poultry (Johnson, 1989). Prolactin is known to stimulate water and mineral intake in lower vertebrates (Altan et al., 2000), rats (Al-Hassan et al., 1987) and humans (Jordan, 2003). Therefore increased prolactin levels under HS conditions, help the animals to maintain water and salt balance and at the same time to regulate their body temperature. Catecholamines (epinephrine and norepinephrine) play an important role in thermoregulation, and their plasma levels may be used as an index of thermal stress (Joseph et al., 1991). Heat stress causes protein structure instability throughout the body leading to deleterious denaturation of various essential proteins (Huston, 1996). There is paucity of information on the impact of heat stress on blood and serum biochemistry hence, the aim of this study was to determine the possible effects of heat stress on haematology and serum biochemistry in albino rats. 
348

\section{Materials and Methods}

Animals

Twenty male rats of three weeks old, weighing between 180 and $200 \mathrm{~g}$ were used for the study. The animals were kept in cages and fed ad libitum with pelleted grower's mash and water. The animals were acclimatized for two weeks.

\section{Ethical approval}

Ethical clearance was obtained from the ethical committee on handling of experimental animals from the University of Nigeria, Nsukka.

\section{Experimental design}

The animals were randomly assigned into two groups of 10 rats each. The animals in group A were housed in a cage and exposed to the sun while those in group B were housed in a cage and kept under a shade. The study lasted for 28 days.

\section{Methods of determining the various parameters}

Pack cell volume (PCV) was determined by microhaematocrit method (Coles, 1986). The hemoglobin concentration (HBC) of the blood samples was determined by the cynomethaemoglobin method (Karchmar, 1970). Red blood cell count was determined by the haemocytometer method (Schalm et al., 1975). Mean corpuscular volume (MCV) was determined by finding the ration of the haematocrit to the red blood cell count. Mean corpuscular haemoglobin concentration (MCHC) was determined by finding the average concentration of haemoglobin (HBC) in average of red blood cell. White blood cell count was determined by the haemocytometer method (Schalm et al., 1975). Differential leucocytes count was determined by the examination of stained blood smear (Koepke et al., 1985). Blood films were made on a clean slide as soon as possible after collection of the blood samples. The blood films were stained with leishmann and examined under the immersion objective to identify the cells. A minimum of 100 cells were enumerated and categorized according to their type. This count was subsequently converted to their absolute count of the specific cells of the leucocytes series (Neutrophils, Eosinophils, Basophils,
Lymphocytes and Monocytes), by multiplying the percentage of cells counted with the total leucocytes count.

\section{Serum enzyme levels}

The serum enzyme levels were determined by the strict adherence to the manufacturer's directives for each serum enzyme assay kit (Teco and randox diagnostic kits.). Total cholesterol (TC) levels and Serum alkaline phosphatase (ALP) levels were determined using the method described by Fielderwald et al. (1972).

Serum alanine amino transferase (ALT) and serum aspartate transferase (AST) were determined using the method described by Kew et al. (1971). Serum total protein (TSP) was determined by the direct biuret test method for in-vitro determination of total protein in serum or plasma (Kew et al., 1971).

\section{Statistical analysis}

Data obtained from the study were analyzed using independent T-test. Differences in values less than a probability of 0.05 were considered significant.

\section{Results}

There were significant increases $(\mathrm{p}<0.05)$ in PCV (days 14 and 15) and RBC (day 14) in group A when compared to group $\mathrm{B}$ (Table 1 ). There was a significant decrease in HBC (day 28) in group A when compared with group B (Table 1). There was a significant decrease in WBC (days 14 and 28) in group A when compared with group B (Table 1). There were significant decreases in MCHC (day 28) and $\mathrm{MCH}$ (days 14 and 28) in group A when compared with group $\mathrm{B}$ and no significant difference in MCV between the two groups (Table 2). There were significant decreases in lymphocytes, monocytes (days 14 and 28) and eosinophyls (day 14) in group A when compared to group B (Table 3 ).

There were significant increases in alanine amino transferase (ALT) on day 28, aspartate amino transferase (AST) on day 28 and total serum proteins (day 14) in group A when compared to B (Table 4). There were significant decreases in alanine phosphatase (ALP) on days 14 and 28 and serum cholesterol on days 14 and 28 in group $\mathrm{A}$ when compared with group B (Table 4).

Table 1. Mean haematology values of the rats

\begin{tabular}{|c|c|c|c|}
\hline Parameters & Days & Group A & Group B \\
\hline \multirow{2}{*}{$\operatorname{PCV}(\%)$} & 14 & $53.20 \pm 1.36^{a}$ & $43.40 \pm 0.60^{b}$ \\
\hline & 28 & $53.0 \pm 1.22^{\mathrm{a}}$ & $43.00 \pm 0.84^{\mathrm{b}}$ \\
\hline \multirow{2}{*}{$\operatorname{HBC}(\mathrm{g} / \mathrm{dl})$} & 14 & $14.0 \pm 0.54$ & $15.28 \pm 0.43$ \\
\hline & 28 & $13.54 \pm 0.57^{\mathrm{a}}$ & $15.46 \pm 0.33^{b}$ \\
\hline \multirow{2}{*}{$\mathrm{RBC}\left(\mathrm{x} 10^{6} / \mathrm{mm}^{3}\right)$} & 14 & $12.57 \pm 0.33^{\mathrm{a}}$ & $9.78 \pm 0.74^{b}$ \\
\hline & 28 & $13.69 \pm 0.60$ & $12.03 \pm 0.78$ \\
\hline \multirow{2}{*}{$\mathrm{WBC}\left(\times 10^{3} / \mathrm{mm}^{3}\right)$} & 14 & $11780.00 \pm 321.56^{\mathrm{a}}$ & $15520.00 \pm 474.76^{b}$ \\
\hline & 28 & $8690.00 \pm 188.06^{\mathrm{a}}$ & $16320.00 \pm 145.43^{b}$ \\
\hline
\end{tabular}

$\mathrm{a}, \mathrm{b}=$ Different superscript indicating significant difference between group $\mathrm{A}$ and $\mathrm{B}(\mathrm{p}<0.05)$ 
Table 2. Mean erythrocytic index values of the rats

\begin{tabular}{cccc}
\hline Parameters & Days & Group A & Group B \\
\hline \multirow{2}{*}{ MCV } & 14 & $42.46 \pm 1.76$ & $45.71 \pm 4.52$ \\
& 28 & $39.84 \pm 2.36$ & $36.42 \pm 4.73$ \\
MCHC & 14 & $2.64 \pm 0.12$ & $2.90 \pm 0.11$ \\
& 28 & $2.51 \pm 0.13^{\mathrm{a}}$ & $3.60 \pm 0.06^{\mathrm{b}}$ \\
$\mathrm{MCH}$ & 14 & $11.17 \pm 0.62^{\mathrm{a}}$ & $16.19 \pm 1.87^{\mathrm{b}}$ \\
& 28 & $9.98 \pm 0.65^{\mathrm{a}}$ & $13.10 \pm 1.03^{\mathrm{b}}$ \\
\hline a, b = Different superscript indicating significant difference between group A and B $(\mathrm{p}<0.05)$ & &
\end{tabular}

Table 3. Mean differential leucocyte count values of the rats

\begin{tabular}{cccc}
\hline Parameters & Days & Group A & Group B \\
\hline Neutrophils $\left(10^{3} / \mathrm{mm}^{3}\right)$ & 14 & $39.60 \pm 19.60$ & $28.80 \pm 0.97$ \\
& 28 & $42.40 \pm 19.60$ & $28.20 \pm 1.62$ \\
Lymphocytes $\left(10^{3} / \mathrm{mm}^{3}\right)$ & 14 & $52.20 \pm 2.20^{\mathrm{a}}$ & $67.80 \pm 1.36^{\mathrm{b}}$ \\
& 28 & $50.40 \pm 1.66^{\mathrm{a}}$ & $68.80 \pm 1.30^{\mathrm{b}}$ \\
Monocytes $\left(10^{3} / \mathrm{mm}^{3}\right)$ & 14 & $1.00 \pm 0.32^{\mathrm{a}}$ & $2.00 \pm 0.71^{\mathrm{b}}$ \\
& 28 & $0.40 \pm 0.32^{\mathrm{a}}$ & $1.60 \pm 0.24^{\mathrm{b}}$ \\
Eosinophils $\left(10^{3} / \mathrm{mm}^{3}\right)$ & 14 & $0.40 \pm 0.024^{\mathrm{a}}$ & $0.80 \pm 0.37^{\mathrm{b}}$ \\
Basophils $\left(10^{3} / \mathrm{mm}^{3}\right)$ & 28 & $0.00 \pm 0.00$ & $1.00 \pm 0.00$ \\
\hline $\mathrm{a}, \mathrm{b}=$ Different superscript indicating significant difference between group A and B $(\mathrm{p}<0.05)$ & $0.60 \pm 0.40$ & $0.60 \pm 0.24$ \\
\hline
\end{tabular}

Table 4. Mean serum enzyme levels of the rats

\begin{tabular}{cccc}
\hline Parameters & Days & Group A & Group B \\
\hline Total serum protein & 14 & $6.00 \pm 0.24^{\mathrm{a}}$ & $4.32 \pm 0.36^{\mathrm{b}}$ \\
$(\mathrm{g} / \mathrm{dl})$ & 28 & $7.34 \pm 1.06$ & $6.70 \pm 0.22$ \\
Alanine aminotransferase & 14 & $44.80 \pm 2.40$ & $41.60 \pm 3.03$ \\
$(\mathrm{~g} / \mathrm{dl})$ & 28 & $43.60 \pm 1.81^{\mathrm{a}}$ & $36.60 \pm 1.96^{\mathrm{b}}$ \\
Alanine phosphatase & 14 & $120.20 \pm 1.85^{\mathrm{a}}$ & $191.60 \pm 9.33^{\mathrm{b}}$ \\
$(\mathrm{g} / \mathrm{dl})$ & 28 & $113.80 \pm 2.20^{\mathrm{a}}$ & $193.60 \pm 9.29^{\mathrm{b}}$ \\
Aspartate aminotransferase & 14 & $147.60 \pm 3.90$ & $141.40 \pm 3.75$ \\
$(\mathrm{~g} / \mathrm{dl})$ & 28 & $146.00 \pm 1.76^{\mathrm{a}}$ & $138.60 \pm 2.09^{\mathrm{b}}$ \\
Serum cholesterol & 14 & $60.80 \pm 2.96^{\mathrm{a}}$ & $87.60 \pm 3.03^{\mathrm{b}}$ \\
\hline $\mathrm{a}, \mathrm{b}=$ Different superscript indicating significant difference between group A and B $(\mathrm{p}<0.05)$ & $57.00 \pm 2.64^{\mathrm{a}}$ & $112.20 \pm 4.15^{\mathrm{b}}$ \\
\hline
\end{tabular}

\section{Discussion}

The significant increase in PCV and $\mathrm{RBC}$ in the heat stressed group when compared with the control probably could be due to decreased oxygen uptake as a result of high ambient temperature or by increased haemo-concentration following possible dehydration occasioned by the heat stress. These results are in line with the findings of Huston, (1996).

The decrease in WBC in the heat stressed group probably was as a result of immunosuppressive effect of corticosteroids which are usually secreted in large amount during stress including heat stress (Mitral et al., 1972). The significant decrease in $\mathrm{MCHC}$ and $\mathrm{MCH}$ of group $\mathrm{A}$ when compared with group $\mathrm{B}$ may be due to decrease in $\mathrm{HBC}$ of group $\mathrm{A}$, although not significant. The differential WBC count showed significant decrease in lymphocytes of group A when compared with group B. Lymphocytic organs such as spleen and thymus become smaller during prolong exposure to high temperature and this may have led to reduction in circulating lymphocytes. This agrees with the report of Kelly et al. (1982).
The results of the serum protein level showed a significant increase in serum proteins of group A when compared with group B on days 14 and 28. This increase may be as a result of the increased production of serum proteins such as albumin by the liver so as to maintain osmoregulation in condition of tissue fluid perfusion as a result of dehydration when animals are subjected to heat stress (Arad et al., 1983).

The result of the serum cholesterol showed a significant reduction in group $\mathrm{A}$ when compared with group $\mathrm{B}$. This may be due to the breakdown of fats in conditions of reduced glucose level there by causing a decreased gluconeogenesis by the liver in conditions of reduced feed intake and decreased metabolic rate. The result of the serum enzyme activity showed significant increase in the activity of alanine- aminotransferase (ALT) and aspartateaminotransferase (AST) in group A when compared to group B. This suggests that exposure to heat stress may have caused damage to the liver. This agrees with the research by Kew et al. (2007) that reported that increase in the level of ALT and AST are reliable markers of liver damage. 
Gaughan JB, Mader TL, Holt SM, Josey MJ, Rowan KJ (1999). Heat tolerance of Boran and Tuli crossbred steers. Journal of Animal Science $77(3): 2398-2405$.

This study revealed that heat stress causes immunosuppression which is very dangerous to animals. Exposed animal may not be able to fight against diseases hence effort should be made to provide shade in animal houses.

\section{Conflict of Interest}

The authors declare that there are no conflicts of interest related to this article.

\section{References}

Al-Hassan DH, Al-Janabi AS, Al-Habouri MS (1987). Effect of summer temperature on some blood characteristics of laying hens. Journal of Agricultural Water Resources 6(2):26-28.

Altan O, Altan A, Oguz I, Pabuccuoglu A, Konyalioglu S (2000). Effects of heat stress on growth, some blood variables and lipid oxidation in broilers exposed to high temperature at an early age. British Poultry Science 41(3):489-493.

Arad Z, Mander J, Eylath U (1983). Serum electrolytes and enzymes responses to heat stress and dehydration in fowl. Comparative Biochemistry 74(1):449-453.

Brosh AY, Aharoni A.A, Wright D, Young BA (1988). Effect of solar radiation, dietary energy and time of feeding on thermoregulatory responses and energy balance in cattle in hot environment. Animal Science 76(1):2671-2677.

Coles EH (1986). Veterinary chemical pathology, $4^{\text {th }}$ edition. WB Saunders Company Philadelphiapp 12.

Cooper MA, Washburn KW (1998). The relationship of body temperature to weight gain. Feed consumption and feed utilization in broilers under heat stress. Poultry Science 77(1):237-242.

Costrini AM, Pitt HA, Gustafson AB, Udine DE (1979). Cardiovascular metabolic manifestations of heat stroke and severe heat exhaustion. American Journal of Medicine 66(3):296-302.

Fielderwald W, Levy R, Fredrickson DS (1972). Clinical chemistry 18(5):495-502. thyroid size of domestic fowl. Poultry Science 41(2):175-183.

Johnson KG, Stark R (1989). Adaptive behavior of laboratory rats feeding in hot conditions. Comparative Biochemistry and Physiology 94(1):69-72.

Jordan ER (2003). Effects of heat stress on reproduction. Dairy Science 86(4):E104E114.

Joseph IM, Suthanthrarajan N, Namasivayam (1991). Effect of acute heat stress on certain immunological parameters in rats, Indian Journal of Physiology and Pharmacology 35(1):269-271.

Kachmar JF (1970). Enzymes: In: Tietz NW (Ed). Fundamentals of clinical chemistry. Sounders, Philadelphia pp 442.

KellyDW, Osborne CA, Evermann SM (1982). Effects of chronic heat and cold stressors on plasma immunoglobulin, mitogen reproduction and induced blastogenesis in calves. Journal of Dairy Science 65(1):1514 1528.

Kew M, Bersohn I, Seftel H (1971). The diagnostic and prognostic significance of serum enzymes changes in heat stroke. Transactions of the Royal Society of Tropical Medicine and Hygiene 65(3):325-330.

Kew M, Bersohn I, Seftel H (2007). Liver damage in heat stroke animals. Journal of Medicine 8(3):49-192.

Koepke JA (1985).Veterinary chemical pathology, $4^{\text {th }}$ edition. WB Saunders Company, Philadelphia pp 19.

Mitra R, Christian GI, Johnson HD (1972). Effects of prolonged thermal exposure on growth hormone secretion in cattle. Animal Science 34(1):776-779.

Roth Z, Meidan R, Shaham-Albalancy A, Braw-Tal R, Wolfenson D (2001). Delayed effect of heat stress on steroid production in mediumsized and preovulatory bovine follicles. Reproduction 121(2):745-751.

Schalm OW, Jain NC, Carrol EJ (1975). Veterinary haematology, 3rd Edition. Lea and Febiger Publication, Philadelphia pp 807-807.

St-Pierre NR, Cobanov B, Schnitkey G (2003). Economic losses from heat stress by US livestock industry.Journal of Dairy Science 86(1):52-77.
Huston TM, (1966). The influence of high environmental temperature on 